\title{
Kriz Yönetiminde Proaktif ve Reaktif Yaklaşım: Covid-19 Krizi Üzerine Bir Değerlendirme
}

\author{
Fatma AKAR*
}

\section{ÖZ}

Covid-19 pandemisi, yaklaşık bir yllır tüm dünyayı etkisine almış olan büyük bir sağlık krizidir. Sosyal, siyasal, ekonomik ve psikolojik etkileri çok ağır olan bu kriz, dünyanın en gelişmiş ülkelerinden en gelişmemiş olanına kadar neredeyse tüm ülkele ri çaresiz bırakmıştr. Çalışsmada, Covid-19 pandemisinden en çok etkilenen beş ülkenin (Çin, ABD, Türkiye, Almanya, İtalya) pandemiye karşı verdiği mücadele kriz yönetimi bağlamında ele alınmıştır. Söz konusu ülkelerin benimsedikleri yaklaşımın kriz yönetim sürecine nasıl yansıdığını belirlemeyi amaçlayan çalışmada literatür taraması yöntemiyle güncel veriler ve kaynaklar taranmış, bu ülkelerin nasıl bir kriz yönetimi yaklaşımını benimsedikleri ve benimsenen yaklaşımın onları başarıya götürüp götürmediği araştırllmıştır. Yapılan inceleme neticesinde, ortaya çıktı̆̆1 günden itibaren pandeminin ciddiyetini anlayan ve buna bağlı olarak erken tedbir alan ülkelerde vaka ve ölüm oranlarının diğer ülkelere göre daha düşük olduğu, ancak pandeminin ciddiyetini anlayamayan ya da gelmekte olan krizi öngöremeyen ülkelerde ise vaka ve ölüm oranlarının daha yüksek olduğu görülmüştür. Sonuç olarak, krizi proaktif bir yaklaşımla engellemeye çalışan ülkelerin pandemi krizini daha iyi yönettiği, bu süreçte reaktif kriz yönetimi yaklaşımını tercih eden ülkelerin ise pandemi ile baş etme noktasında daha büyük krizlerle karşı karşıya kaldıkları tespit edilmiştir.

Anahtar Kelimeler: Covid-19, Kriz Yönetimi, Proaktif Yaklaşım, Reaktif Yaklaşım

\section{Proactive and Reactive Approach in Crisis Management: An Assessment on the Covid-19 Crisis}

\begin{abstract}
The Covid-19 pandemic is a major health crisis that has affected the whole world for about a year. This crisis, political, economic and psychological effects of which are very heavy, has left almost all countries, from the most developed countries to the most underdeveloped ones, desperate. In the present study, the struggle of the five countries (China, USA, Turkey, Germany, Italy) most affected by the Covid-19 pandemic was discussed in the context of crisis management. In the study, which aims to determine how the approach adopted by these countries is reflected in the crisis management process, current data and resources were scanned with the literature review method, and it was investigated what kind of crisis management approach these countries adopted and whether this approach leads them to success have been examined. As a result of the examination, it has been observed that the cases and death rates are lower in countries that have understood the severity of the pandemic since the day it emerged and have taken early measures accordingly, but the case and death rates are higher in countries that cannot understand the severity of the pandemic or cannot predict the coming crisis. As a result, it has been determined that countries trying to prevent the crisis with a proactive approach manage the pandemic crisis better, and countries that prefer a reactive crisis management approach in this process face greater crises at the point of coping with the pandemic.
\end{abstract}

Keywords: Covid-19, Crisis Management, Proactive Approach, Reactive Approach

\section{Giriş}

Çin'in Vuhan eyaletinde 2019 Aralı'ta ortaya çıan ve kısa süre içinde neredeyse tüm dünyayı etkisi altına alan koronavirüs (Covid-19) 11 Şubat'ta Dünya Sağlık Örgütü tarafindan pandemi olarak ilan edilmiştir. Çin'in Vuhan şehrinden dünyaya yayılan koronavirüs salgını kısa sürede tüm dünyayı etkisi altına almıştır. Düne kadar robotlanın dünyayı ele geçireceği, nano teknoloji ile devrimler yaratılacağ1 dillendirilirken, bugün insanlar bu fikirlerini bir tarafa bırakarak çaresiz bir şekilde evlerinde oturmak zorunda kalmışlardır. Hem bireysel bazda hem de toplumsal düzeyde etkileri gözlenen bu kriz, ülkelerin birçok sorunla karşı karşıya gelmelerine sebep olmaktadır.

Covid-19 krizini diğer krizlerden ayıran en önemli nokta, bu pandeminin tek bir ülkeyi ya da bölgeyi değil tüm dünyayı etkileyen bir salgın olmasıdır. Literatür taraması yöntemiyle güncel veriler ve kaynakların tarandığı çalışmada 20 Nisan 2020 tarihi itibariyle dünya salgın sıralamasında ilk on içerisinde yer alan (Çin, ABD, Rusya, Türkiye, İspanya, Belçika, Almanya, İngiltere, İtalya, Fransa) ülkelerden beşinin (Çin, ABD, Türkiye, Almanya, İtalya) pandemiye karşı vermiş olduğu mücadele, kriz yönetimi bağlamında ele

\footnotetext{
* Öğr. Gör. Dr., Bolu Abant İzzet Baysal Üniversitesi, fatmaakar@ibu.edu.tr
} Makalenin Gönderim Tarihi: 28.11.2020; Makalenin Kabul Tarihi: 10.01.2021 
alınmaktadır. Bu kapsamda çalışma içerisinde her bir ülkede pandemi sebebiyle gerçekleşen ilk ölümün yaşandığ1 tarih baz alınarak, bu tarihten itibaren geçen iki aylık süre zarfinda ülkelerdeki vaka ve ölüm sayıları grafik şeklinde sunulmaktadır. Yine bu süre zarfında incelenen ülkelerin pandemiye karşı aldığ1 önlemler ve attığı adımlar ise proaktif ve reaktif kriz yaklaşımı bağlamında değerlendirilmektedir.

Pandeminin dünya genelinde yayllım hızı ve oranı her geçen gün farklılık göstermektedir. Bu durum pandemiden en fazla etkilenen ülkelerin sıralamasının değişmesine sebep olmaktadır. Çalışmanın ele aldığı süre içerisinde birinci ülke olan $\mathrm{ABD}$ haricinde tüm sıralamanın değiştiği görülmüştür. Çalışmada bu değişimi göstermek için 22 Ekim 2020 tarihi itibari ile söz konusu ülkelerin koronavirüs tablolarına bir kez daha bakılmıştır.

Genel manada çalışma, Covid-19 pandemisi ile yoğun bir şekilde mücadele etmek durumunda kalan beş ülkenin bu salgını nasıl yönettiklerini, kriz yönetiminde nasıl bir yaklaşım tercih ettiklerini ve tercih ettikleri kriz yönetimi yaklaşımının onları başarıya ulaştırıp ulaştırmadığını ortaya koymayı amaçlamıştır.

\section{Kriz ve Kriz Yönetimi Kavramı}

Beklenmedik bir şekilde ortaya çıkan ve meydana geldiği kurum ya da toplumda olumsuz sonuçlar doğuran olaylar olarak tanımlanan kriz kavramının kökeni, eski Yunan'da karar manasına gelen "krisis" kelimesine dayanmaktadır. Belirtmek gerekir ki, burada belli bir karar anı değil, bir durumdan diğerine geçiş süreci içinde yaşanan bir "kararsızlık anı" ifade edilmektedir (Genç, 2005, s. 334).

Kriz kelimesi, farklı disiplinlerde çalışan araştırmacılar tarafindan çeşitli şekillerde tanımlanmıştır. Krizi örgütsel düzeyde ele alan Tagraf ve Aslan (2003, s.150) krizi “önceden sezilemeyen ve beklenmeyen, örgüt tarafından hemen karş1ık verilmesi gereken, örgütün önleme ve uyum mekanizmalarını yetersiz duruma getirerek, mevcut değerlerini, hedeflerini ve varsayımlarını tehdit eden gerilim durumu" şeklinde tanımlamışlardır.

Benzer şekilde Kernisky (1997, s. 843) krizi; "bir örgütün beklentileri ile çevresinde gerçekleşenler arasındaki büyük uyumsuzluk" olarak tanımlamıştır. Kırdar ve Otay Demir (2007, s. 94) ise krize daha kapsamlı yaklaşmışlar ve bu kapsamda krizi "bir toplumun, bir kuruluşun veya bir kimsenin yaşamında görülen güç dönem, bunalım ya da buhran" olarak tanımlamışlardır.

Kriz yönetimi ise muhtemel kriz durumuna karşıllk, kriz sinyallerinin alınarak değerlendirilmesi ve örgütün kriz durumunu en az kayıpla atlatabilmesi için gerekli olan önlemlerin alınması ve uygulanması sürecidir (Can, 1999, s. 318-320). Peker \& Aytürk (2000, s. 55-61) yaptıklanı çalşsmada etkili kriz yönetiminin gerekleri olarak potansiyel sorunları önceden tespit etmeyi ve söz konusu sorunları krize dönüşmeden önlemeyi sıralamışlardır. Benzer bir şekilde Akdağ (2005, s. 2) kriz yönetiminde en önemli hususun, kurumu tehdit eden olaya hızlı bir şekilde müdahale edilmesi ve bu kapsamda hayata geçirilmesi gereken stratejilerin gecikmeksizin belirlenmesi olduğunu belirtmektedir.

Kriz yönetimi sürecinde, sorunları her zaman önceden tespit etmek, önlemek mümkün olmadığından dolayı karşı karşıya kalınan krizin etkilerinin sınırlanmasına yönelik adımlar atılmasının yanı sıra sorunlar ortaya çıtıklarında hızlı bir şekilde tepki gösterilmesi gerekir.

Bu kapsamda krizden başarıyla çımak için kriz yönetiminin bazı özelliklere sahip olması gerekir (Haşit, 2000, s. 66-67).

- Krizi yönetecek kişilerin algilama kapasiteleri kriz yönetiminde önemli yer tutmaktadır. Krizleri önlemede başarı, yöneticilerin krizleri ne şekilde algıladıklanına bağlı olarak değişebilmektedir.

- Kriz yönetimi devamllil̆g esas olan bir durumdur. Öncesi ve sonras1 yoktur. Önceden tahmin edilebilen krizlerle ilgili hazırlanan planların sürekli olarak denenmesi, yeniden gözden geçirilmesi uygun olacaktır.

- $\quad$ Kriz yönetimi ortaya çıkan krizlerin türlerine uygun olarak oluşturulmalıdır.

- Kriz yönetiminde başarının ödülü çok büyük olabilmektedir. Krizi başarılla atlatan kriz yönetimi, yöneticilerin kendilerine olan güvenlerini ve morallerini güçlendirmektedir. Krizleri başarılyla atlatabilmiş yöneticiler görevlerini sağlamlaştırmanın yanında kariyerlerinde yeni bir döneme başlamaktadırlar.

- Krizin yönetilmesi çok önemli, gerekli, zor ve hatta karmaşık bir süreci içermektedir. Bundan dolayı krizlerin hemen çözülmesi beklenmemelidir. Uzun ve sıkıntıll bir süreç olan krizi başarılı bir şekilde atlatmak yaratıcı düşünceye sahip olmayı, objektif ve cesaretli kararlar almayı, grup çalışmasını 
benimsemeyi, her an harekete hazır, yeniliğe taraf olan, beklenmedik her türlü istek ve koşullara hazırlıklı olmay1 gerektirmektedir.

- Kriz yönetiminde, iletişim, kontrol, maliyet, kültür, düzenleme, durum planlaması, sistemlerin karmaşıklığı ve birbirine bağlllığı gibi önemli faktörler yer almaktadır. Bu faktörler kurumun kriz reçetesini oluşturmaktadır. Ayrıca örgütün değerleri ve inançları doğrultusunda krizlerin yönlendirilmesi de krizin çözümünde önem taşımaktadır.

\section{Kriz Yönetim Sürecinin Aşamaları}

Mackenzie (1995, s. 73-74) krizlerin önceden kestirilmesinin oldukça zor olduğunu, bunun yerine oluşmasını engelleyici ya da durdurulamadığında sonuçlarını minimuma indirecek adımların atılmasının daha önemli olduğunu belirtmektedir. Buna karşın Kazancı (2014, s. 22) ise her krizin bir anatomisi olduğunu ve ayrıntılı bir inceleme ile krizin gelişini tahmin etmenin mümkün olacağını belirterek, bunu başaran kurumların şüphesiz krize karşı daha hazırlıklı olacaklarını dile getirmektedir.

Krizler, kurumlar1 strese sokan kayg1 verici durumlar olmakla birlikte iyi yönetilmeleri durumunda yeni firsatların ve yeni gelişmelerin de habercisi olabilmektedirler (Arklan, 2014, s. 209). Kurumların kriz durumlarından başarıly çıkmalanı, iyileşmenin yeniden sağlanması, risklerin tamamen ortadan kaldırılması için kriz yönetiminin etkili bir şekilde uygulanması gerekmektedir.

Genel olarak kriz yönetimi beș aşamada gerçekleşir. Bu aşamalardan ilki sinyal tespiti aşamasıdır. Krizler kendilerini tamamen göstermeden önce, muhataplarına erken uyarlar gönderirler. Kriz sinyalleri, yaklaşmakta olan krizin varlığı ve şiddeti ile ilgili bazı bilgileri yansıttığından dolayı, yöneticiler bu sinyallere karşı dikkatli ve uyanı olmalıdırlar. Kriz bu sinyallerin iyi izlenmemesi ve gerektiği gibi değerlendirilememesi sonucunda meydana gelir. Kriz sinyallerinin alınabilmesi ise örgütte çeşitli sinyalleri ve işaretleri algılayabilen erken uyarı sistemlerinin kurulmasını ve çalıştırılmasını gerektirir (Can, 1999, s. 318; Akat vd., 2002, s. 413).

Krizin gelişim süreci, bir hastalığın gelişim sürecine benzetilebilir. Bir hastalık had safhaya ulaşana kadar, nasıl birtakım belirtiler verirse, kriz de tüm şiddeti ile ortaya çıkmadan önce bir takım uyarı sinyalleri göndermektedir. Bir hastalığa ilişkin belirtilerin zamanında fark edilerek erken teşhisinin gerçekleştirilmesi, tedaviyi ne kadar kolaylaşturrsa, krizin gönderdiği erken uyarı sinyallerinin belirlenmesi de krizin ortaya çıkışının engellenmesini o kadar kolaylaştırmaktadır (Ataman, 2001, s. 256).

Kriz yönetiminin ikinci aşaması hą̧rlk/önleme aşamasıdır. Bu aşama krizin kaçınılmaz olarak yöneticilerin dikkatini çektiği aşamadır. Yöneticiler, krizin bir kuluçka dönemi yaşamış olduğunu ancak henüz algilanabilir hale geldiğini fark ederler. Şayet organizasyonun erken uyarı sistemleri kriz sistemlerini yakalamışsa kriz önleme ve korunma mekanizmalan harekete geçirilir, kriz planları devreye sokulur, üst yönetimde bu doğrultuda hareket etmeye başlar, kriz yönetim ekibi şekillendirilir. Ancak bazı durumlarda söz konusu tüm şartlar yerine getirildiği halde örgüt, kriz durumundan kurtulamayabilir. Dolayısiyla yöneticilerin, kriz seyrini sürekli takip etmesi ve gerekli önlemleri almaya devam etmesi gerekmektedir (Semercioğlu, 2007, s. 3). Yöneticilere bu aşamada çok fazla iş düşmektedir. Bu işler şu şekilde siralanabilmektedir (Regester, 1989, s. 79-80).

- Kriz yönetimine karşı olumlu bir tutum oluşturulmalıdır.

- İşletme performansı toplumun beklentilerini karşılayacak seviyeye getirilmelidir.

- Faaliyetlerde sorumluluğun başarılması yoluyla güven oluşturulmalıdır.

- Kriz sırasındaki fırsatları değerlendirmek için hazırlıklı olunmalıdır.

- Bir kriz yönetim takımı belirlenmelidir.

- Potansiyel kriz durumlan belirlenmelidir.

- Potansiyel kriz durumlarını engellemek için politikalar geliştirilmelidir.

- Potansiyel bir krizle mücadele etmek için strateji ve taktikler geliştirilmelidir.

- $\quad$ Risk ve kriz kontrolü saptanmalıdır.

- Kriz planı yazıya dökülmelidir.

- Kriz planı test edilmelidir.

Üçüncü aşama krį̧ denetim altına alma aşamasıdır ki bu aşamada savunma ve önleme mekanizmaları herhangi bir zaaf belirtisini aktif bir şekilde meydana çıarabilmelidir. Sonra kriz yönetiminden sorumlu 
ekip, nerede zafiyet varsa, onu ortaya çıkarmak ve belirlemek durumundadır. Eğer erken uyarı sistemleri, düzenli aralıklarla izlenmezse, hazırlık ve önleme mekanizmaları da doğru çalışmayacaktır. Bu aşama mümkün olduğunca, hem çıkacak krize karşı hazırlık aşamasını hem de krizi kontrol altına almak amacıyla onun yönünü başka tarafa çevirme aşamasını içerir. Bu yapılmadığı taktirde, organizasyonun yapı ve süreçlerinde, daha evvelki bozukluklar daha çok büyüme eğilimi gösterir ve krizi yönetmek imkansız hale gelir. Krizi denetim altına alma, ancak örgütçe kontrol edilebilecek ve zararları sınırlandırılabilecek, yani yönetilebilir krizler için mümkündür. Bunun mümkün olmasının yanında, kriz yönetimi ekibinin gerekli eğitim düzeyinde olmasi gerekir (Genç, 2005, s. 350-351).

Kriz yönetiminin bir diğer aşaması normalleşme aşamasıdır. Kurumda normalleşmenin başladığı bu aşamada önceden geliştirilmiş ve denenmiş, kısa ve uzun dönemli iyileşme mekanizmaları uygulanmaya çalışlır. Başka bir deyişle bu aşama kaybedilenin yerine konmaya çalışıldığı bir süreçtir. Ancak bu birdenbire değil kademeli olarak gerçekleşir. Bu iyileşme ortamında yapılması gereken, işlerin normale dönebilmesi için gerekli kaynakların, işlemlerin ve personelin önceden belirlenen hedefler doğrultusunda yönlendirilmesini sağlamaktır. Bu aşamanın birinci amacı krizin çözümlenmesi, sonraki amacı ise krizden mümkün olan faydanın sağlanmasıdır (Uzun, 2001, s. 58).

Kriz yönetiminin son aşaması ise öğrenme aşamasıdır. Bu aşama krizden çıkarılan derslerin tartışıldığı aşamadır. Kriz sonucunda kurum bir durum analizi yöntemi olan SWOT analizini yaparak güçlü ve zayıf yanlarını, karşılaşabileceği yeni firsatları ve tehditleri görebilir. Bu analiz sayesinde güçlü yanlarını daha da güçlendirebilir, zayıf yönlerini güçlendirmek için çabalayabilir, ortamdaki fırsatları değerlendirip tehditlere karşı önlemler alabilir.

Gelmekte olan, belirtileri netleşen ve ortamı endişelendiren krizden en az zararla çıkmanın yolu, belirli bazı önlemleri almaktan geçer. Bu konuda akla ilk gelen konu, krizden kaçmanın mümkün olup olmayacağıdır. İlk aşamada gerekli önlemleri asgari düzeyde bile olsa, almak pek kimsenin aklına gelmez. Bu durumu öngören bir hazırlık, kuruluşun yararına sonuç verecektir. Ön inceleme için bir uzman ekip hemen kurulur ve işe başlanır (Augustine, 1999, s. 19'dan Akt. Kazancı, 2014, s. 22).

Kriz yönetimi örgütte kriz yönetimi ekibi tarafindan gerçekleştirilir. Kriz yönetim ekibinin görevi örgüttün karşllaşabileceği potansiyel kriz faktörlerini tespit edip önlemek için tedbirler almak ve meydana gelen krizleri örgütün en az zararla atlatması için çalışmaktır. Kriz yönetim ekibi karar alıcı ve uygulayıcılardan oluşur ve karşılaşlan krizi yönetmek için yetkililerden ve uzmanlardan oluşan bir kurul halinde çalışır. Kriz yönetim ekibinin ilk hedefi krizi önlemek olmalıdır (Özdemir, 2014, s.88).

\section{Kriz Yönetiminde Proaktif ve Reaktif Yaklaşım}

Kriz yönetimi sadece bir krizin ortaya çıkması sonrasında gerçekleştirilen faaliyetleri değil, kriz ortaya çıkmadan alınan kararları ve atılan adımları da kapsamaktadır. Bu kapsamda bir kurum kriz ekibini, kriz senaryolarını ve yararlanılacak iletişim araçlarını kriz öncesinde ya da kriz ortaya çıktıktan sonra belirleyebilmektedir. Kriz ortaya çıkmadan önce önlemlerin alınması veya kriz ekibinin oluşturulması proaktif bir yaklaşım iken; kriz meydana geldikten sonra etkilerini azaltmak amacıyla gerçekleştirilen çalışmalar ise reaktif kriz yönetimi kapsamında değerlendirilmektedir (Akar, 2014, s. 445).

Kurumların kriz durumlarındaki yaklaşımlarını krize verdikleri tepki belirler. Aldıkları kriz sinyallerinin gücüne göre proaktif ya da reaktif bir yaklaşım gösterebilirler (Regester \& Larkin, 2005'ten Akt, Manzoni, 2015 , s. 2). Proaktif (aktif kriz yönetimi) yaklaşım, kurumların daha kriz ortaya çıkıp kurumu tehdit etmeden kriz ihtimalini düşünerek gerekli adımları atmaları anlamına gelmektedir.

Aslında bütün krizler, tam olarak ortaya çıkmadan önce erken uyarı sinyalleri gönderirler. Eğer bu sinyaller yöneticiler tarafından doğru okunur ve muhtemel sorunların giderilmesi yönünde etkili bir şekilde hareket edilirse, çoğu kriz oluşmadan önce önlenebilmektedir. Bu yöntem proaktif kriz yönetimi yaklaşımıdır. Proaktif yaklaşımda, örgütlerin sürekli olarak bütün operasyonlarını iç, dış ve yakın çevrelerini erken uyarı sinyallerini alabilmeleri ve bunlan düzeltebilmeleri için taramalanı gerekmektedir (Ural, 2003, s. 385). Krizin ortaya çımasını beklemek yani potansiyel krizlere karşı hiçbir önlem almamak bir kurumun yapacağı en önemli hata olacakttr.

Krizden kaçmak için muhtemel krizlere karşı öncelikle bazı önlemlerin alınması gerekir. Bu önlemlerin en önemlisi ve ilk sırada yer alanı ise ortam analizinin yapılarak tehditlerin belirlenmesidir. Kriz çıkarma 
potansiyeli olan tehditler belirlendikten sonra bu tehditleri ortadan kaldırmak için önleyici stratejiler geliştirmek gerekir (Tutar, 2007, s. 77). Diğer bir ifadeyle krizi önleyebilmek için örgütlerin kriz yönetimde proaktif yaklaşımı tercih etmeleri önem arz eder. Bu kapsamda kriz önleme süreci üç aşamadan meydana gelmektedir. Bunlar; araştırma ve kaynakların tespiti, ortam taraması ile bilgilerin toplanması ve toplanan bilgilerin analiz edilmesidir (Coombs, 2012, s. 47). Bu üç aşamada başarılı olan kuruluşlanın krizin sinyallerini erken dönemde sezinlemeleri ve kriz kendilerini ve ilgili paydaşlarını tehdit etmeden onu çözümleyerek atlatmaları mümkün olacaktır.

Bazen kriz sinyalleri alınsa da ekonomik kayg1lar, bize bir şey olmaz düşüncesi ve algilanan gerçekleri ifşa etmeme gibi nedenlerle görmezden gelinebilmektedir. Nitekim koronavirüs pandemisinde de çoğu ülke koronavirüs Çin'de ortaya çıktığında, hastalığın orayla sınıllı kalacağını ve kendilerini etkilemeyeceğini düşünmüşler ve herhangi bir önlem almaya gereksinim duymamışlardır. Yani yaşanması muhtemel olan kriz, sinyallerini iletmesine karşın birçok ülke gerekli önlemleri zamanında almamış ve çok daha fazla vaka ve ölüm oranlarıyla karşı karşıya kalmışlardır. Ülkelerin sergilemiş oldukları yaklaşıma benzer bir yaklaşım, çoğu zaman kurumlarca da sergilenmektedir. Ural (2003, s. 385) kurumların da proaktif davranmanın önemini kavramakta zorlandığını belirterek; birçok kurumun bizim başımıza gelmez, kriz yönetimine ve krize hazırllğa gerek yok diye düşündüklerini dile getirmektedir.

Reaktif yaklaşım bir anlamda proaktif yaklaşımın tersi bir anlayışla hareket etmeyi yansıtır. Bu yaklaşımda ortaya çıkan ve kurumun hayati organlarını ve işleyişini tehdit eden krizin ortadan tamamen kaldırilması ya da olumsuz etkilerinin minimuma indirilmesi hedeflenmektedir. Pira ve Sohodol (2004, s. 28) reaktif kriz yönetimi yaklaşımını benimsemiş örgütlerin, yani herhangi bir kriz yönetim ekibi ya da kriz yönetim planı bulunmayan, kriz sinyallerini görmezden gelen, sergilemiş olduğu yaklaşımla krizi yok sayan ve gelişmeleri gerektiği gibi takip etmeyen örgütlerin kendilerini ciddi sıkıntıya sokacak farklı problemlerden kaçınmalarının çok zor olacağını belirtmektedirler. Problemlerle karşı karşıya kalan örgütler hayatta kalmak ve faaliyetlerini sürdürebilmek adına karşı stratejiler geliştirirler ki bu stratejiler genellikle savunmaya dayalı stratejilerdir (Solmaz, 2006, s. 151).

Proaktif kriz yönetimi yaklaşımı; saldırgan bir yapıya reaktif kriz yönetimi yaklaşımı ise savunmacı bir yapıya sahiptir (Dinçer, 2004, s. 423-424). Yine proaktif yaklaşım daha çok firsat yaratmaya ve imaj yükseltmeye hizmet ederken; reaktif yaklaşım ise krizin patlak vermesinden sonraki süreçte gerçekleştirilenleri kapsadığından dolayı daha çok krizin etkilerini ortadan kaldırma, mevcut durumu koruma ya da bozulan imaji onarmaya hizmet etmektedir.

\section{Covid-19 Krizinde Ülkelerin Kriz Yaklaşımları}

Yaşanan kriz aynı olsa da ülkelerin söz konusu krize verdikleri tepkiler birbirinden farklılık göstermektedir. Burada, çalışma kapsamında örneklem olarak alınan Çin, ABD, Türkiye, Almanya ve İtalya'nın koronavirüs salgınına yönelik aldığı önlemler ve attı̆̆1 adımlar kriz yönetimi yaklaşımları açısından değerlendirilmektedir.

\section{1. Çin ve Covid-19 Krizi}

Salgın hastalıkların neden olduğu krizler, tupkı doğal afet krizleri gibi aniden ve beklenmedik şekilde ortaya çıkarlar. Aniden ve beklenmedik şekilde ortaya çıkmaları bu tür krizlerin kontrol edilmelerini zorlaştıran bir faktördür. Ancak bu durum söz konusu krizin yönetilemeyeceği anlamina gelmez. Eğer ülkeler bu tarz salgınları öngörüp gerekli sağlı yatırımlarını zamanında yaparlar ise daha az hasar ile kurtulabilirler.

Koronavirüs salgınının ilk ortaya çıktığı ülke Çin olmuştur. Söz konusu virüsün neden olduğu ilk vaka 2019 yllının son günlerinde Çin'in Vuhan kentinde ortaya çıkmış ve ilk başta zatürre olduğu düşünülmüştür. Çinli yetkililer 31 Aralık 2020 tarihinde Dünya Sağlık Örgütüne Vuhan kentinde 41 kişide zatürre benzeri bir hastalık olduğunu bildirmiş, ancak yapılan analizler neticesinde bunun zatürreye neden olan bir virüs olmadığı anlaşılmıştır. Bu süreçte ABD Hastalık Kontrol ve Korunma Merkezi, 1 Ocak 2020 'de yaptığ açıklamada virüsün Vuhan'daki deniz ürünleri pazarından kaynaklanıyor olabileceğini açıklamış ve bu açıklamaya hızlı bir şekilde tepki veren Çinli yetkililer 1 Ocak'ta bu pazarı kapatma kararı almışlardır. Kapatma kararını yeni tedbirler izlemiş ve 3 Ocak günü Vuhan'a gelen ve Vuhan'dan giden 
yolcular havaalanlarında sağlık kontrollerinden geçirilmeye başlanmıştır. 7 Ocak 2020'de söz konusu virüsün zatürreye neden olan bir virüs olmayıp yeni bir virüs çeşidi olduğu ve doğrudan solunum yollarını etkileyen bu virüsün 2019-nCoV olduğu açıklanmıştır. 11 Ocak gününe gelindiğinde ise Çin'de bu virüs yüzünden ilk ölüm gerçekleşmiştir (https://medyascope.tv).

22 Ocak'ta Çin'de vaka sayısı 550'yi aşmış ve ölü sayısı 17'ye yükselmiştir. 23 Ocak tarihinde ise Vuhan'a tüm ulaşım durdurulmuş ve şehirde karantina tedbirleri uygulanmaya başlanmışırı. 24 Ocak'ta Çin Seddi'nin de içinde bulunduğu birçok turistik bölge ziyarete kapatılmıştır. 25 Ocak'ta Hubey eyaletinde 17 kente ulaşım durdurulmuş ve aynı gün Çin yeni yılı etkinlikleri iptal edilmiştir. Yukarıda sayılan karantina kararları ile 27 Ocak tarihi itibari ile 18 şehirde 56 Milyon kişi karantina altına alınmıştır (www.amerikanınsesi.com). 11 Şubat'a gelindiğinde ise Çin'de vaka sayısı 40 bini, can kaybı ise 1000’i aşmıştır (www.aa.com.tr). Çin hükümeti artan vaka ve ölüm sayıları ile, tedbirleri de arttırmaya başlamıştır. 17 Şubat'ta ülkede vahşi hayvanların tüketiminin ve ticaretinin yasaklanması için yasa tasarısı hazırlanmıştır. Bu alınan tedbirler 18 Şubat'ta meyvesini vermeye başlamış ve Çin'deki vaka sayısındaki artış ilk defa 2 binin altında kalmıştır. 22 Şubat'ta ise günlük vaka sayılarında düşüş başlamıştır. (www.amerikanınsesi.com).

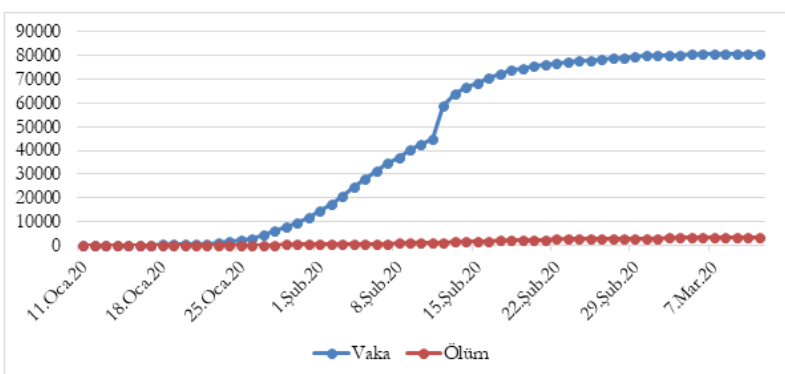

Grafik 1. Çin Koronavirüs Vaka ve Ölüm Sayıs1 (11 Ocak-11 Mart)

(Kaynak: https://www.worldometers.info/coronavirüs/countries)

Grafik-1'den de görüldügüu üzere ülkenin dikey olarak ilerleyen vaka sayısı 22 Şubat tarihinden itibaren yataya dönmüştür. İlk ölümün görüldüğü gün olan 11 Ocak'tan yaklaşık bir buçuk ay sonra Çin'de vaka sayılarında düşüş başlamıştır. Bu düşüşte ülke yönetiminin çok hızlı ve katı tedbirler uygulaması etkili olmuştur. Şöyle ki Çinli yetkililer virüsün tespit edildiğini Dünya Sağllk Örgütüne bildirdiklerinin ertesi günü yani 1 Ocak'ta canlı hayvan pazarını kapatmışlardır. Bu tarihten sonra tedbirler birbirini izlemiş ve ülke adeta bir açık cezaevine dönüşmüş, hükümet insanları evde tutmak için askeri ve polis gücünü kullanmıştır. Çin’in aldığ1 bu katı karantina önlemleri hastalığ1 taşıyan insanlar ile risk grubunda yer alan insanlar arasındaki teması önleyerek virüsün yayllım zincirini başarıyla kırmıştır.

Mart ayı ile birlikte ülkede sokağa çıkma kısıtlamaları yavaş yavaş gevşetilmiştir. Bu kapsamda her haneden bir kişinin sokağa çıkmasına izin verilmiş, alsşveriş merkezleri açılmış, toplu taşıma araçları çalışmaya başlamıştır. Çin'deki normalleşme adımlarında sosyal mesafe ve maske kuralı çok kalabalık bir ülke olmasına karşın katı bir şekilde işletilmiştir (www.bbc.com).

Tüm dünyada ikinci dalganın yaşandığı ve birçok ülkenin salgının ilk zamanlarındaki vaka oranlarını gördüğü bu günlerde, Çin'in 22 Ekim 2020 koronavirüs tablosuna bakıldığında toplam vaka sayısının 85.729, yeni vaka sayısının 14, toplam ölüm sayısının 4.634 olduğu ve koronavirüse bağlı yeni ölümün ise olmadığ1 görülmüştür (www.worldometers.info). Sonuç olarak Çin reaktif kriz yönetimi yaklaşımını benimseyerek savunma stratejisi uygulamıştır ancak hızlı davranarak aldığı katı önlemler sayesinde, ülkenin nüfusu ile vaka ve ölüm oranları kıyaslandığında tüm dünyayı etkisi altına alan ve dünyanın en gelişmiş ülkelerinin bile üstesinden gelmekte zorlandığı hatta başarısız olduğu bu krizi başarılı bir şekilde yönettiği görülmüştür.

Çin hükümetinin başarılı olmasında en önemli etken ortaya çımasına engel olamadığı koronavirüs salgınına reaktif kriz yönetimi yaklaşımı doğrultusunda yaklaşması ve ortaya çıkan salgından en az kayıpla çıkabilmek için koronavirüs salgınına hızlı bir şekilde tepki vermesi olmuştur. Proaktif yaklaşım her ne kadar krizlerin önlenmesinde en etkili yaklaşım olarak düşünülse de bütün krizlerin bu yaklaşımla 
önlenmesi mümkün olmamaktadır. Önlenemeyen ve bu sebeple vuku bulan krizlerin en az kayıpla atlatılması için alınan kararların ve atılan adımların tamamını reaktif kriz yönetimi kapsamında değerlendirmek mümkündür.

\subsection{ABD ve Covid-19 Krizi}

ABD yönetimi ve özellikle Başkan Trump, salgının başladığı ilk aylarda umursamaz bir tavır sergilemiştir. Salgın tehdidinin boyutlarını anlamakta çok geç kalan Trump, yaptığı bir konuşmada yeni tip koronavirüsün, Demokratlar tarafindan kendisine ve yönetimine zarar vermek için kullanılan bir aldatmaca olduğunu söylemiştir. Ancak Mart ayının sonlarına gelindiğinde ABD'de açıklanan resmi rakamlara ve Grafik-2'ye bakıldığında 80 binden fazla kişi virüse yakalanmış ve 2 bin 800 'den fazla kişi hayatını kaybetmişti. Ülkede artan vaka ve ölüm oranları koronavirüsün ne denli tehlikeli olduğunu iyiden iyiye hissettirmesi ile birlikte Trump'ın söylemlerinde ve eylemlerinde radikal bir değişim meydana gelmiştir. Trump, bu kez virüse karşı verilen mücadeleyi bir savaş olarak nitelendirmiştir (www.yenihaberden.com). Ülke yönetiminin salgının gelişini çok önceden haber almasına rağmen, gerekli önlemleri zamanında almaması vaka ve ölüm oranlarnnda ABD'nin ilk sıraya yükselmesine sebep olmuştur.

$A B D$ yönetiminde halk sağlı̆ına öncelik vermek isteyenler ile ekonomiye öncelik vermek isteyenler şeklinde iki farklı eğilim ortaya çıkmıştır. Başkan Trump ikinci eğilime daha yakın olduğundan, salgına değil daha çok ekonomiye ve kendi seçim çalışmalarına odaklanmışır. Ancak ülkede vaka sayılarının artması bir anlamda Trump’1 da önlem almaya zorlamıştır (www.bbc.com).

ABD, Çin'de ilk vakaların ortaya çıkmaya başlamasından ancak bir ay sonra virüsün yayılmasına yönelik önlemler almaya başlamışır. 31 Ocak 2020'de Trump, fiziksel olarak Çin'de bulunmuş olan yabancıların ABD’ye girişinin kısıtlanmasına yönelik yapılan düzenlemeyi onaylamıştır. ABD Dışişleri Bakanlı̆̆ı'nın Çin'e seyahat uyarısı yapmasının ardından Amerikalı birçok hava yolu şirketi Çin ile ABD arasında uçuşları en az iki ay durdurma kararı almıştrr. Ayrıca Trump yönetimi son 14 günde Çin'e seyahat eden yabanc1 ülke vatandaşlarını ülkeye almama kararı almıstır. Karara $A B D$ vatandaşı ya da oturum izni olanların aile üyeleri dahil edilmemiştir (https://www.amerikaninsesi.com). İlerleyen günlerde İran ve Avrupa'dan gelenler içinde aynı önlemler alınmış ve İtalya ve G.Kore'den gelenler için zorunlu taramaların yapılması istenmiştir (www.whitehouse.gov). Bu önlemlere ek olarak ülkede ekonomiyi ayakta tutmak için teşvik paketleri açıklanmışır. İlk teşvik paketinde tüm Amerikalılar için ücretli izin, genişletilmiş işsizlik sigortası ve gida güvenliği gibi önlemler yer almıştır (www.vox.com).

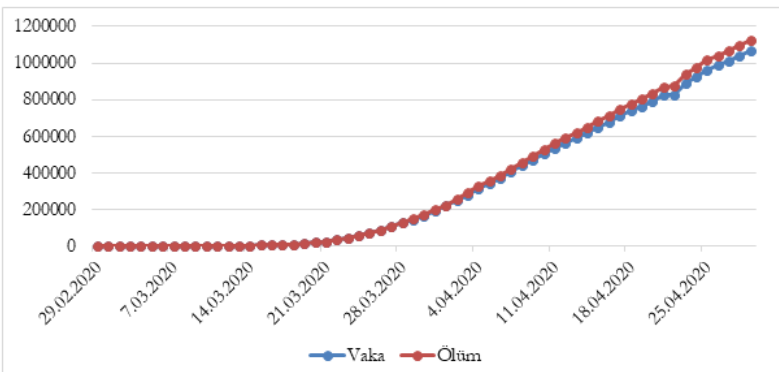

Grafik 2. ABD Koronavirüs Vaka ve Ölüm Sayısı (29 Şubat-29 Nisan)

(Kaynak: https://www.worldometers.info/coronavirüs/countries.)

Ülke içinde okulların, eğlence yerlerinin kapanması gibi sıkı tedbirlerin alınması ancak Mart ayının sonunda gerçekleşmiştir. Yine Mart ayından itibaren eyaletler de kendi içinde ek tedbirler almış, birçok eyalette sokağa çıma yasakları ilan edilmiş, kafeler, barlar ve gece kulüpleri kapatılmıstır. Ancak ABD'nin vaka ve ölüm oranlarının verildiği Grafik-2'den de görüldügü gibi alınan tedbirlerin salgınla mücadelede etkili olmadığı görülmektedir. Bunun en önemli sebebi alınan önlemlerin ilk vakanın görülmesinden yaklaşık iki ay sonra alınmaya başlamasıdır. Trump yönetimi ekonomiyi öncelediği için tedbir almada geç kalmış ve bu durum bir yandan ülkenin sağlık sistemine daha büyük bir yük getirmiş öte yandan da sağllk sisteminde yaşanan aksaklıkların gün yüzüne çıkmasına ve eleştirilere sebep olmuştur. 
$\mathrm{ABD}$, hakkaniyet prensibine dayanmayan sağlık hizmetleri sisteminin salgında nasıl sonuçlar verdiğini gösteren çarpıcı bir örnek olmuştur. Ülkede özel hastaneler ve özel sağlık sigortaları üzerine kurulu eşitsiz bir sistem vardır ve 2019'daki bir araştırmaya göre ülkedeki nüfusun yüzde 9,1'nin hiçbir sağlık sigortası bulunmamaktadır. Bu kriz döneminde ABD sadece testi ücretsiz hale getirmiş, ancak testi pozitif çıan kişilerden sağlık sigortasına sahip olmayanlar büyük sıkınt yaşamışlardır. Bu şekilde sıkıntı yaşayan kişilere bir nebze olsun yardımcı olabilmek adına bazı eyaletler, düşük gelirli kesimlerin sağılı sigortasına erişimini kolaylaştıran 'Medicaid' isimli bir uygulamaya geçmiştir. Ama bu uygulamanın ülke geneline yayılması mümkün olmamıştır (www.haberler.boun.edu.tr).

Salgının birinci dalgasında kısa bir süre içinde vaka ve ölüm sayılarıyla diğer ülkeleri geride bırakarak ilk sıraya oturan ABD, birinciliğini ikinci dalgada da diğer ülkelere kaptırmamışır. 22 Ekim 2020 ABD koronavirüs tablosuna bakıldığında; toplam vaka sayısının 8.585.748, günlük yeni vaka sayısının 929, toplam ölümün 227.419 ve yeni ölüm oranının ise 107 olduğu görülmüștür. Bütün bu veriler dünyanın süper gücü ABD’nin böylesi bir sağılk krizine karşı hazırlıklı olmadığını ortaya çıarmıştır.

ABD'nin başarısız olmasının birçok nedeni sayılabilir ancak en önemli sebep olarak Trump yönetiminin krizin ciddiyetinin farkına varmaması ve krize zamanında müdahale etmemesi gösterilebilir. Ayrıca ülke nüfusuna oranla yeterli testin yapılamaması ve Amerikan sağllk sistemindeki eksiklikler de bu süreçte başarısız olunmasına sebep olmuştur.

Ekonomik ve siyasi kaygılar sonucu geç tedbir almasıyla ve sağlık sistemindeki adaletsizlikle dünyanın en gelişmiş ekonomisi olan $\mathrm{ABD}$, bu pandemide sınıfta kalmıştır. ABD bu sağlık krizini yönetmede proaktif yaklaşımın gereği olan önlem almayı beceremediği gibi reaktif yaklaşımın gereği olarak düşünülebilecek sorunu çözme, ortadan kaldırma ya da en az kayıpla atlatma hamlelerini de başaramamıştır.

\subsection{Türkiye ve Covid-19 Krizi}

Çin'de salgının etkilerinin her geçen gün artması ve çevre ülkelerde de görülmeye başlaması Türkiye'yi hızla tedbir almaya yöneltmiştir. Türkiye, Dünya Sağlık Örgütü'nün Covid-19’u pandemi olarak ilan etmesinden tam 36 gün önce (6 Ocak 2020) Sağlık bakanlığ1 bünyesinde koronavirüse karşı bir operasyon merkezini, 10 Ocak'ta ise hükümete tavsiyeleriyle bu süreçte yol gösterecek olan Koronavirüs Bilim Kurulunu oluşturmuştur. Bu önlemleri 14 Ocak'ta Sağlık Bakanlığının ilk Covid-19 rehberini hazırlaması ve 20 Ocak'ta ise Çin, ABD ve Rusya'dan gelen yolcuların ateşlerinin ölçülmesi izlemiştir (www.bbc.com).

Türkiye'de salgınla ilgili ilk açıklama 22 Ocak'ta gelmiştir. Sağlı Bakanı Fahrettin Koca yaptı̆ı açıklamada "Şu an Dünya Sağlık Örgütü termal kamerayı Türkiye için önermiyor ama bu anlamda termal kamera dahil bütün hazırlıklarımızı yaptığımızı özellikle söylemek istiyorum. Tedirgin olunmaması, şu an Türkiye için herhangi bir riskin söz konusu olmadığını özellikle belirtmek istiyorum” demiştir (www.amerikaninsesi.com). Sağlık Bakanı yaptığı bu açıklama ile Türkiye'nin her türlü riske karşı önlemlerini henüz salgin ülkeye girmeden almaya başladığını kamuoyuna duyurmuştur. Bu açılamaya ve alınan tedbirlere dayanarak Türkiye'nin salgına karşı mücadelesini proaktif bir yaklaşımla gerçekleştirdiğini söylemek mümkündür.

Sıralanan tedbirleri 24 Ocak'ta Çin'e seyahat edecek kişilere seyahat uyarısının yapılması izlemiştir. 31 Ocak'ta ise THY Çin'deki dört noktaya uçuşlarını önce 9 Şubat'a kadar sonrasında ise süresiz olarak durdurma kararı almıştır. 3 Şubat'ta Çin'den tüm uçuşlar, 23 Şubat'ta İran'da salgının yayılmasıyla birlikte bu ülkeden kara, hava ve demiryolu ulaşımı ve 29 Şubat'ta ise Irak, İtalya ve Güney Kore'yle uçuşlar durdurulmuştur. 11 Mart tarihinde ise ülkede ilk vakanın görüldüğü bizzat Sağllk Bakanı tarafindan duyurulmuştur (www.bbc.com).

İlk vakanın tespitinin ardından ek tedbirler uygulamaya sokulmuştur. Bu tedbirler kapsamında 16 Mart'ta ilk ve orta öğretim kurumlarında iki haftalı̆ına üniversiteler de ise üç haftalı̆̆ına eğitime ara verilmiştir. Daha sonra ise her kademe eğitim kurumlanında eğitimlerin uzaktan yapılması kararlaştırılmıştır. Yine alınan tedbirler kapsamında hafta sonları 30 büyükşehirde ve Zonguldak'ta sokağa çıkma yasağı uygulanmıştır. 17 Mart'ta gelindiğinde ise Türkiye'de Koronavirüs kaynaklı ilk ölüm yaşanmıştır. İlerleyen zamanlarda vaka ve ölüm oranlarının artmasıyla birçok devlet hastanesi ve özel hastane pandemi hastanesi ilan edilmiştir. Vakaların illere göre dağılımı açıklanmayarak insanların 
bulundukları yerlerde sabit kalmaları sağlanmış ve salgının ülke geneline yayılımının önüne geçilmiştir. Diğer bir ifadeyle İtalya'nın düştüğü hataya düşülmemiştir. Aynı zamanda daha fazla risk gurubu içinde olduğu düşünülen 65 yaş üstü vatandaşlara ve virüs bulaşının artması noktasında taşıyıcı olarak görülen 20 yaş altı gençlere sokağa çıkma kısıtlaması getirilerek de hem salgının yayılımı önlenmiş hem de bu gruplar koruma altına alınmıştır.

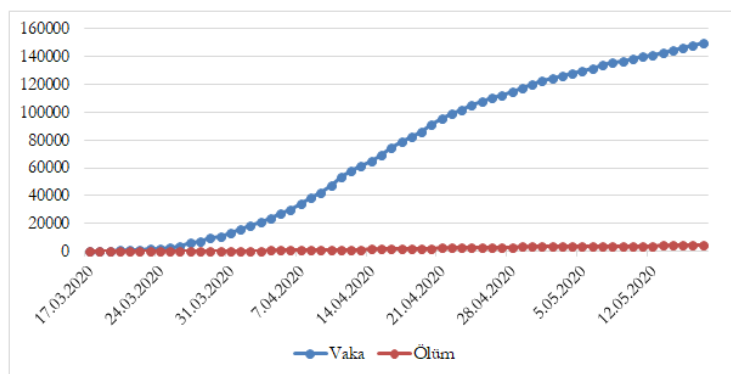

Grafik 3. Türkiye Koronavirüs Vaka ve Ölüm Sayıs1 (17Mart-17 Mayıs)

(Kaynak: https://www.worldometers.info/coronavirüs/countries.)

Grafik-3 incelendiğinde Türkiye'de bir günde görülen en yüksek vaka sayısı 11 Nisan'da görülmüştür. Nisan ayı sonlarına kadar vaka sayılarında ve ölüm oranlarında yükseliş devam ederken; 26 Nisan'da ilk defa iyileşen sayısı vaka sayısını geçmiş ve bu tarihten sonra vaka ve ölüm sayılarında düşüş başlamıştır. Mayıs ayına gelindiğinde vaka ve ölüm oranlarındaki düşüşe paralel olarak alınan sıkı tedbirler kademeli olarak gevşetilmiş ve nihayet Haziran ayı ile birlikte vaka sayısının 1000'in altına düşmesi sonucu salgınla birlikte getirilen tüm kısıtlamalar belirli kurallara uyulması koşuluyla kaldırılmıştır. İki ay gibi bir süre zarfinda salgının ilk dalgasının kısmen de olsa kontrol altına alınması ve ABD ve Avrupa ile karşılaştırıldığında bu süreçte düşük vaka ve ölüm oranlarına sahip olması Türkiye’nin bu salgında başarılı bir kriz yönetimi sergilediği şeklinde yorumlanabilir.

Türkiye'nin ilk dalgadaki sergilediği başarıya etki eden faktörler arasında yaşanan krizin bizzat Sağlık Bakanı tarafindan sahiplenilmesi/yönetilmesi, kriz sözcülügünün üstlenilmesi, halkı bilgilendirme noktasında her gün düzenli açıklama yapılması ve oluşturulan Bilim Kurulu'nun önerileri doğrultusunda gerekli tedbirlerin alınması sayılabilir. Öte yandan pandeminin ilk ortaya çıktığı andan itibaren, proaktif bir yaklaşım benimsenerek ülke içinde ve dışında hareketliliğin kısıtlanması için alınan kararların ve attlan adımların da bu sürecin kontrol altında tutulmasında etkili olduğu söylenebilir. Türkiye aldığı bu tedbirler sayesinde, sağlık hizmetlerine talep patlamasının yaşanmadığı bir ülke olmuştur.

Genel olarak bakıldığında Türkiye'nin bu krizi birçok gelişmiş ülkeden daha iyi yönettiğini söylemek yanlış olmayacaktır. Grafik-3'e bakıldığında alınan tedbir ile hastalığın bir buçuk ay gibi bir sürede durağan hale geldiği görülmektedir. Türkiye'nin bu başarısında sağlık sistemi ve donanımlı hastaneler önemli rol oynamıştır.

Pandeminin ilk dalgasını proaktif davranarak iyi bir şekilde yöneten Türkiye, diğer tüm ülkeler gibi vaka sayılarının düşmesiyle birlikte Haziran ayından itibaren ekonomik sebeplerle normalleşme sürecine girmiştir. Ancak bu süreç hastalığın yayılımını artırmış ve Eylül ayı ile birlikte vaka sayılarında yükseliş başlamıştır. Türkiye'nin vaka ve ölüm oranları incelendiğinde ülkeler sıralamasında 22.10.2020 tarihi itibari ile 21. sırada yer aldığı (www.worldometers.info) görülmektedir. Diğer ülkelerle kıyaslandığında vaka ve ölüm oranları düşük olsa da tedbirlerin gevşetilmesine paralel bir şekilde bu oranlar her geçen gün artmaktadir.

\subsection{Almanya ve Covid-19 Krizi}

Covid-19 Almanya'da ilk olarak Münih kentinde 27 Ocak’ta tespit edilmiştir. Covid-19 testi pozitif çıkan kişi ve virüsü bulaştırdığı kişiler, Alman yetkililer tarafından yakın bir şekilde takip edilerek virüsün yayılımı kontrol altına alınmıştır. Bu kişilere karşı etkin bir şekilde yürütülen filyasyon çalışmalarına karşın, ilk vakanın görüldüğü tarihte ülke çapında herhangi bir önlem alınmamış, normal hayat devam etmiş ve organizasyonlar iptal edilmemiştir. Bu manada 15 Şubat'ta Hollanda sınırına yakın bir kasaba olan 
Gangelt’te 300 kişinin katıldığı karnaval sonrasında ülkede Covid-19 vakalarında artış yaşanmışstır. Bu karnaval Almanya'da pandeminin başlangıcı olarak kabul edilmektedir (www.aa.com.tr).

Söz konusu karnaval kutlamalarından iki hafta sonra Kovid-19 vakalanında artış yaşanmıştır. Pozitif vaka sayıs1 5 Mart tarihinde 400 iken Grafik-4 incelendiğinde 10 Mart tarihinde bu sayı bin 296'ya yükselmiştir. Yine grafiğe bakıldığında özellikle Şubat sonu, Mart başından itibaren vaka sayısının, hızlı bir şekilde artmasına rağmen bu tarihlerde de sokağa çıkma yasağı/kısıtlaması veya sosyal mesafe uygulamaları kapsamında herhangi bir önlem alınmamıştır. Almanya genelinde sokağa çıkma kısıtlaması, restoranların kapatılması ve sosyal mesafenin korunmasına yönelik ilk önlemler ise 22 Mart tarihinde alınmıştır. $\mathrm{Bu}$ tarihte vaka sayısı Almanya genelinde 24 bin 873'e yükselmiştir. Özetle, Almanya'nın Kovid-19'un yayılmaya başladığı ilk zamanlarda virüsü fazla ciddiye almadığı, bazı önlemlerin uygulanmasında geç kaldığ1 söylenebilir. Almanya, yeni tip koronavirüs salgınına geç tepki vermesi ve salgının yavaşlatılması için elzem önlemleri almakta yavaş hareket etmesine rağmen, şans faktörünün ve güçlü sağlık sisteminin yardımıyla ilk şoku atlatıp salgını kontrol altına almayı başarmıştı (www.aa.com.tr).

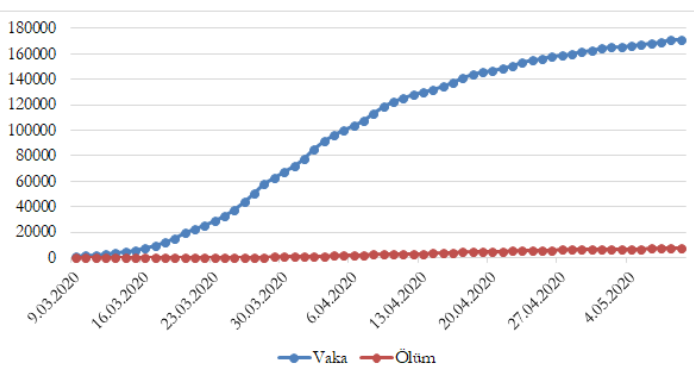

Grafik 4. Almanya Koronavirüs Vaka ve Ölüm Sayıs1 (9 Mart-9 Mayıs)

(Kaynak: https://www.worldometers.info/coronavirüs/countries)

Bu süreçte Almanya'nın pandeminin önlenmesine yönelik sanki proaktif bir yaklaşım sergilemediği gibi bir algılayış oluşsa da bu ülkenin daha öncesinden sağlık sistemine yaptı̆̆ yatırım ve hazır bulunmuşluk hali göz önüne getirildiğinde aslında proaktif bir yaklaşımı benimsediği söylenebilir. Ancak şu da bir gerçek ki proaktif yaklaşım kapsamında alınan tedbirlerin bütün krizleri önlemesi de mümkün değildir. Bu sebeple özelde Almanya'nın genel de ise tüm ülkelerin aslında baş edilmesi hayli zor olan bu pandemi krizine yönelik hem proaktif hem de reaktif yaklaşımın gereklerini farklı düzeylerde de olsa yerine getirdikleri ifade edilebilir.

Öte yandan Almanya'da 22 Ekim 2020 itibari ile toplam vaka 403 bin 874, toplam ölüm 87.730 ve yeni vaka 12.519, koronavirüsten yeni ölüm sayısı ise 45 olarak gerçekleşmiştir. Bu sayılara bakıldığında Almanya'da da diğer ülkeler de olduğu gibi salgının ikinci dalgasında vaka oranlarının tekrar tırmanışa geçtiği görülmektedir. Yine de diğer Avrupa ülkeleri ve ABD ile karşılaştırıldığında ve yüksek vaka sayısına karşın ölüm oranlarının düşük olması göz önüne getirildiğinde bu ülkenin virüsle mücadelede başarılı olduğu söylenebilir.

Almanya'nın bu başarısı, yeterli sağılk altyapısına, ekipmanına ve yetişmiş sağlık personeline sahip olmasıyla açıklanabilir. Gelişmiş araştırma kurumlarıyla, erken dönemde yeterli testi üreterek, yapılan testlerden hızlı sonuç alınması, Almanya'yı diğer Avrupa ülkelerinden farklılaştırmıştır. Dolayısıyla erken teşhis ve tedavi imkanının sağlanması Almanya'ya virüsle mücadelede avantaj sağlamıştır. Pandemi başladığında Almanya'nın, 28 bin solunum ünitesine sahip olması ve yoğun bakım yatak kapasitesi ile de diğer Avrupa ülkelerinden oldukça önde olması krizi daha kontrollü bir şekilde yürütmesine olanak tanımış ve bu durumda salgından daha az etkilenmesine yol açmıştır (Miş, 2020: www.kriterdergi.com).

\section{5. İtalya ve Covid-19 Krizi}

Çin'de ortaya çıkan koronavirüs maalesef Çin sınırları içinde kalmamış hızla tüm dünyaya yayılmıştır. Bu yayılım Uzak Doğu ülkelerinden sonra ilk olarak Avrupa'ya sıçramıştır. Avrupa'da ise ilk etkilenen ülke İtalya olmuştur. İtalya'nın çok turist alan bir ülke olması ve tehlikenin geç fark edilip önlem almada da geç kalınması İtalya'yı Avrupa'da pandeminin merkezi haline getirmiştir. İtalya'da ilk koronavirüs vakası, 23 
Ocak'ta iki Çinli turistte ve 6 Şubat'ta hastalığın çıktı̆̆ Vuhan'dan dönen bir İtalya vatandaşında görülmüştür (www.aa.com.tr.). 22 Şubat'ta ise koronavirüs kaynaklı ilk ölüm gerçekleşmiştir. 22 Şubat'ta görülen ilk ölüm vakasına rağmen İtalya halkı hastalığı çok ciddiye almamış ve hükümetin uyarılarına rağmen normal hayatlarına devam etmişlerdir (www.milliyet.com).

Hükümet ilk ölümün gerçekleştiği 22 Şubat'ta pandeminin yayıldığı on bir belediyeyi "kırmızı bölge" ilan ederek okulları tatil edip evden çıkma yasağı getirmiştir. Ancak bu önlemler pandeminin yayılımını durduramamış hatta İtalya AB ülkeleri içinde en hızlı arışıın olduğu ülke haline gelmiştir. Bu artışın virüsün ortaya çıktığ 1 Çin dışında dünyadaki ikinci en yüksek artış olduğu görülünce, 4 Mart’ta yurt genelinde ilk, orta ve yükseköğretim kurumlarında eğitime ara verilmiştir. 8 Mart'inta ise vakaların en yoğun görüldüğ̈̈ Lombardiya bölgesi, 9 Mart'ta ise tüm ülke karantinaya alınmışır (www.aa.com.tr). Peki virüs neden Çin'den bu kadar uzak bir ülkede bu kadar hızlı yayılmışır. Bu durumu uzmanlar İtalya'nın kültürel yapısına, nüfus yapısına, sağlık sistemindeki yetersizliklere ve İtalyan hükümetinin kriz yönetimindeki başarısızlığına bağlamaktadırlar.

Koronvirüs vaka ve ölüm oranlarının arttığı ülkede hükümet ek önlemler almak zorunda kalmıştr. 9 Mart'ta İtalya Başbakanı tarafından açıklanan yeni tedbirlere göre; tüm ülke de karantina ilan edilmiş, iş ve sağlık nedenleri haricinde tüm seyahatler yasaklanmış, okullar 3 Nisan’a kadar kapatılmış, tüm spor etkinlikleri durdurulmuştur. Ayrıca cenaze törenleri de dahil olmak üzere dini törenler süresiz askıya alınmıs, tiyatro, sinema, gece kulübü, müze, spor salonu, havuz, kayak tesisleri kapatılmış, restoran ve kafelerin ise 06-18 saatleri arasında açık kalmasına karar verilmiştir (www.bbc.com).

İtalya'nın koronavirüs vaka ve ölüm oranlarını gösteren Grafik-5'e bakıldığında 22 Şubat'tan itibaren ülkede vaka ve ölüm oranlarının hızla arttığı Mart ayı ile birlikte ise vaka sayısının binin üzerine çıktığ1 görülmektedir. İlk ölümüm görüldüğü tarihten yaklaşık üç hafta sonra yani 10 Mart’ta vaka sayısı 10 bini aşmıştı.

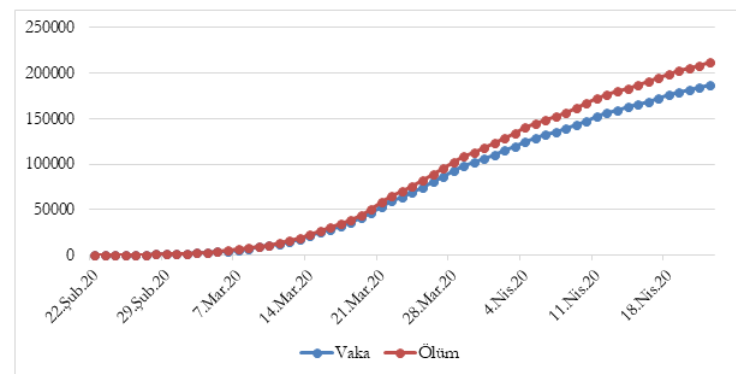

Grafik 5. İtalya Koronavirüs Vaka ve Ölüm Sayısı (22 Şubat-22Nisan)

Kaynak: https://www.worldometers.info/coronavirüs/countries

Yukarıda yer alan grafikteki verilere bakarak İtalyan hükümetinin virüsün yaylımını durdurmak için önlem almada geç kaldığ1 ya da aldığı önlemlerin vaka ve ölüm oranlarını azaltmada yeterli olmadığını söylemek mümkün, ancak ülkede virüsün bu hıla yayllmasında tek etken yeterli tedbirin alınmaması ya da tedbirlerin yetersiz olması değildir. Özellikle koronavirüsün bağışıklığ zayıf olan ve kronik hastalığ1 bulunan yaşlıları daha fazla etkiliyor olması ve İtalya’nın da yaşlı nüfusunun en yüksek olduğu Avrupa ülkesi olması bu ülkede görülen vaka ve ölüm sayısının fazla olmasina neden olmuştur.

Öte yandan İtalya'da vaka sayısının fazla olmasının bir diğer nedeni de virüse karşı geç tedbir alınmış olmasıdır. İtalya Çin'e uçuşlanı ilk vakaların görülmesinden yaklaşık bir buçuk ay sonra durdurmuştur. Yine sorunun bu denli büyümesinin bir diğer nedeni İtalya'daki sağlık sektörüdür. Ülke Avrupa ülkeleri içinde en düşük yatak sayısına sahiptir. Bu nedenle hastaneler kendilerine başvuran ve testi pozitif çıkan hastalar arasından seçim yapmak durumunda kalmış ve birçok hasta evlerine gönderilmiş bu da vaka sayısını arttırmıştır (www.ekonomist.com).

İtalya'ya salgının ikinci dalgasında bakıldığında Coronavirüs dünya sıralamasında on dördüncü sırada olduğu, Avrupa ülkeleri sıralamasında ise üçüncü sırada olduğu görülmüştür. 22 Ekim 2020 itibari ile İtalya'daki vaka sayıs1 465.726, günlük vaka sayıs1 16.079, toplam ölüm 36,968, günlük ölüm sayısı ise 136 olmuştur (www.worldmeters.info). 
Yeni vaka ve ölüm sayılanı tüm dünyada olduğu gibi İtalya'da da koronavirüsün yeniden tırmanışa geçtiğini göstermektedir. Bu durum İtalyan hükümetinin yeniden tedbirler almasına yol açmıştır. İtalya koronavirüs vakalarının çok önceden görülmesine rağmen geç tedbir almasıyla ve sağlık sistemindeki yetersizlikler nedeniyle bu krizde iyi bir snav verememiştir. Krizin iyi yönetilememesi ülkede 22 Ekim itibari ile toplam 37.479 kişinin ölmesine yol açmışır. Krizin ikinci dalgasında da İtalya’nın durumu pek iyi görünmemekle birlikte ülke Avrupa ülkeleri içinde şu an da üçüncü ülke konumundadır.

\section{22 Ekim 2020 İtibariyle Dünya Geneli Koronavirüs Panaroması}

Tablo 1. Dünya Genelinde Corona Virüs Mevcut Durum (22/10/2020)

\begin{tabular}{|c|c|c|}
\hline Toplan Vaka & Toplam İyileşen & Toplam Ölüm \\
\hline 41.734 .887 & 31.059 .565 & 1.139 .647 \\
\hline \multicolumn{2}{|c|}{ Kaynak: https:/ www.worldometers.info/coronavirüs/countries. }
\end{tabular}

Tablo-1 incelendiğinde 22.10.2020 tarihi itibari ile dünyada 41 milyondan fazla insanın bu hastalığa yakalandı̆̆1, bu insanların 31.059.565'inin uygulanan tedavi yöntemleri ile sağlıklarına kavuştuklant, 1.139.547 kişinin ise hayatını kaybettiği görülmektedir. Aslında bu veriler bize dünyanın ne denli önemli bir kriz ile karşı karşıya kaldığını göstermektedir. Ayrıca Tablo-1'de yer alan bu veriler her geçen gün artmaya devam etmekte. İnsanlık tarihinde daha önce insanoğlunun yaşadığı pandemilerdeki vaka ve ölüm oranları ile karşılaştırıldığında tespit edilen vaka ve ölüm oranlarının oldukça düşük olduğu görülmektedir. $\mathrm{Bu}$ durumun ortaya çıkmasında günümüzün gelişen teknolojisi ve sağlık sistemindeki gelişmelerin etkili olduğu söylenebilir. Ancak pandeminin tüm dünyada henüz kontrol altna alınamadı̆̆ düşünüldügünde yine de ülkelerin tüm imkanlarına rağmen bu pandemi ile mücadelede çok çaresiz kaldığını söylemek yanlış olmayacaktır.

Tablo 2. Covid-19 Vaka ve Ölüm Oranlarının Ülkelere Göre Dağılımı (22.10.2020).

\begin{tabular}{|c|c|c|c|c|}
\hline Ülkeler & Toplam Vaka & Yeni Vaka & Toplam Ölüm & Yeni Ölüm \\
\hline ABD & 8.585 .748 & 74.689 & 228.387 & 972 \\
\hline İtalya & 465.726 & 16.079 & 36.968 & 136 \\
\hline Almanya & 403.874 & 12.519 & 10.044 & 45 \\
\hline Türkiye & 355.528 & 2.102 & 9.584 & 71 \\
\hline Çin & 85.729 & 14 & 4.634 & 0 \\
\hline \multicolumn{7}{r}{} \\
\hline
\end{tabular}

Covid-19 pandemisinin neden olduğu vaka ve ölüm oranlarının çalışmada ele alınan ülkelere göre dağılımına 22 Ekim 2020 tarihi itibari ile Tablo-2'den bakıldığında Dünyanın süper gücü ABD'nin 8.585.748 vaka ile ilk sırada yer aldığı görülmektedir. ABD, sadece çalışmada ele alınan ülkeler içinde değil, tüm ülkeler içerisinde de vaka ve ölüm sayısı en fazla olan ülkedir. ABD'yi 465.726 vaka ile İtalya takip etmektedir, üçüncü sırada 403.874 vaka ile Almanya yer almaktadır. Dördüncü sırada 355.528 vaka oranı ile Türkiye, son sırada ise Covid-19'un ilk ortaya çıktı̆ı Çin 83.729 vaka oranı ile yer almaktadır.

\section{Sonuç}

Kriz dönemleri aslında öyle bir süreç ki hem bireylerin hem kurumların hem de genel manada toplumun ya da ülkenin gidişatını olumsuz yönde etkileyen onları strese sokan gelişmelerin yaşandığı, soğukkanlı, mantıklı ve çabuk cevap vermenin bir anlamda zorunluluk olduğu zaman dilimleridir. $\mathrm{Bu}$ çalışmada 2019 sonunda başlayan ve içinde bulunduğumuz tarihlerde de hala devam eden Covid-19 krizi ele alınmıştır.

Dünya var olduğundan bu yana çok sayıda pandemi yaşanmış ve milyonlarca insan bu pandemilerde can vermiştir. Bu pandemiler bazen tek bir bölgeyi etkilerken bazen de tüm dünyayı etkisi altına almıştur. Covid-19 pandemisi de Çin'de başlayıp çok kısa sürede tüm dünyaya yayılmıştır. Bu pandemi insanların tüm yaşam şeklini etkilemiş ve ülkeleri sosyal, siyasal ve ekonomik olarak olumsuz yönde etkilemiştir. İnsanlar belirli sürelerle evlerinde karantina da kalmışlar, işlerine okullarına gidemez en temel ihtiyaçları dışında dışarı çıkamaz olmuşlardır. İnsanların işe gidememesi üretimin sekteye uğramasına yol açmış bu da 
ülkelerin ekonomik olarak zor durumda kalmasına sebep olmuştur. Bu pandemi ile karşılaşan ülkeler pandemiye karşı çok çeşitli tepkiler vermişlerdir. Bazıları pandemi kendi ülkelerine ulaşmadan tedbir alma yolunu tercih ederken bazıları ise pandemi ülkelerinde görüldükten sonra harekete geçmişlerdir.

Salgının ilk haftalarında, "bu her zaman olduğu gibi Asya'da veya Afrika'da ortaya çıkmış bir virüs, muhtemelen de oralarda kalır" gibi bir tavır içerisinde olan Batılı ülkeler gerçeğin böyle olmadı̆̆ını çok hızlı ve üzücü bir şekilde fark ettiler. Salgın coğrafyaları ve etnik yapıları görmüyordu. Tedbirleri dikkatle ve zamanında almayan ülkeler, sağlık altyapıları yeterli olsa bile üzücü sonuçlarla yüz yüze gelmekten kaçamadılar. Özellikle uluslararası hareketliliği yüksek modern liberal toplumlar büyük can kayıplarıyla yüzleşmek zorunda kaldı. (Kireçci, 2020: https://kriterdergi.com/)

Çalışmada ele alınan ülkelerden Çin koronavirüs pandemisinin başladığı ülke olmasına ve sahip olduğu nüfus yoğunluğuna rağmen zamanında aldığı sıkı önlemlerle iki ay gibi kısa bir sürede pandemiyi kontrol altına almayı başarmıştır. Alınan sıkı önlemler kadar yapılan test sayısındaki fazlalık ve başarılı izolasyon ve filyasyon çalışmaları da bu başarının elde edilmesinde önemli diğer unsurlar olmuştur. İkinci dalgada Çin yine aldığı önlemler ile vaka sayısını sınırlamayı başarmış gibi görünüyor.

ABD'ne baktığımızda ise dünyanın süper gücünün bu pandemide sınıfta kaldığını söylemek yanlıș olmayacaktır. ABD hala en fazla vaka sayısının görüldügüü ülke konumundadır. Ülkenin bu durumda olmasının sebebi salgının ciddiyetini geç anlamaları, krizi görmezden gelmeleri, ekonomik kaygıları ön planda tutmaları ve bunların sonucu olarak tedbir almakta geç kalmaları olduğu söylenebilir. ABD hükümeti koronavirüs ile ilgili bilgilere diğer ülkelerden çok önce ulaşmalarına rağmen proaktif bir yaklaşım sergileyememişler ve krizin içinden çıkılamaz bir hal almasına neden olmuşlardır.

Araştırmamızda incelediğimiz bir diğer ülke olan Almanya ise geç tedbir almasına rağmen güçlü bir ekonomiye ve sağlık sistemine sahip olmasından dolayı Avrupa ülkeleri ve ABD'ye göre bu pandemide başarılı bir grafik çizmektedir. Almanya zamanında hızlı ve çok sayıda test yaparak pozitif vakaların neredeyse tamamını belirlemiştir. Erken teşhis ve tedavi imkanının sağlanması Almanya'ya virüsle mücadelede avantaj sağlamıştır. Ayrıca salgının daha çok gençler arasında yayılması ve kültürel olarak aile ilişkilerinin zayıf olduğu bir ülke olması hastalığın yaşlı insanları bulaşmasını engellemiştir. Bu da ülkede ölüm oranlarını düşürmüştür. Sonuç olarak Almanya'nın kriz öncesinde ülke politikası kapsamında proaktif yaklaşıma uygun hareket ettiğini pandeminin engellenememesine paralel olarak bu kez, sağlık krizinden en az kayıpla çıkmak için reaktif yaklaşımın tüm gereklerini yerine getirdiğini söyleyebiliriz. Yine güçlü ekonomisi ve sağlık sisteminin de etkisi ile Almanya'nın krizi diğer ülkelere göre daha iyi yönettiği söylenebilir.

Avrupa ülkeleri içinde İtalya pandeminin birinci dalgasında vaka ve ölüm sayısı ile koronavirüsten en çok etkilenen ülke olmuştur. İlk vakaların Ocak ayı içinde tespit edilmiş olmasına rağmen hükümetin salgını önlemek için harekete geçmesi Mart ayının ortasını bulmuştur. Bu tedbirlerin alınması sırasında planlamanın düzgün yapılamaması ve salginın ciddiyetinin halka iyi anlatılamaması nedeniyle durum içinden çıkılamaz bir hal almıştır. Halk okulların kapatılmasını bir tatil olarak algıladığı için bulundukları yerlerden ayrılıp başka yerlere tatile gitmişler bu da hastalığın ülke geneline yayılmasına yol açmıştır. Ayrıca bu salgın İtalyan sağlık sisteminin yetersiz olduğunu da gün yüzüne çıkarmışır. Hastane, personel ve ekipman sıkıntısı nedeniyle hastalara gerekli olan sağlık hizmeti verilememiştir. Salgının ikinci dalgasında da İtalya yine vaka ve ölüm oranlan ile hem Avrupa ülkeleri içinde ve hem de bu çalışmada ele alınan ülkeler içinde üçüncü sırada yer almaktadır. Özetle bu kriz İtalya’nın böylesi bir pandemi ile başa çıkabilecek sağlık alt yapısına sahip olmadığını ve sonrasında ise kriz yönetiminde sınıfta kaldığını göstermiștir.

'Türkiye'nin ise diğer ülkelerle karşlaş̧ırıldığında daha proaktif yaklaştığını söylemek mümkündür. Türkiye, ilk vakanın görüldügü günlerden itibaren hızlıca tedbirler almaya başlamışır. 31 Ocak'ta hava ulaşımına ilişkin kısıtlamalanı getirilmesi, ilk vakanın görülmesinin hemen sonrasında tüm seviyelerde uzaktan eğitime geçilmesi, 65 yaş üstüne ve 20 yaş altına sokağa çıkma kısıtlamaları getirilmesi en dikkat çeken tedbirler arasındadır. Bu tedbirleri bazı şehirlerle sınırlı olarak hafta sonları sokağa çıkma yasakları izlemiştir. Alınan bu tedbirler Türkiye'nin vaka sayılarının diğer ülkelere göre daha aşağılarda kalmasını sağlamıştır. Ayrıca bu kriz ülkenin güçlü bir sağlık sistemine sahip olduğunu da ortaya çıkarmıştır. Hastanelerde diğer ülkelerdeki gibi bir yoğunluk yaşanmamıştır. Ancak Haziran ayından itibaren tedbirlerin 
kaldırılması vaka sayılarının yeniden tırmanışa geçmesine yol açmıştır. Yine de Tablo-2'de ki 22 Ekim 2020 verilerine göre çalısmada ele alınan diğer ülkelere göre daha iyi durumda olduğu görülmektedir.

Özetle ülkelerin koronavirüs krizini yönetme biçimleri, birbirinden farklı olmuştur. Kimisi gelmekte olan tehlikeyi önceden görüp yani proaktif davranıp erkenden tedbir almayı tercih ederken (bu ülkelere örnek olarak Türkiye'yi verebiliriz) bazılanı (ABD ve İtalya gibi) ise krizi ciddiye almayarak tedbir almayı gereksiz bulmuşlar ve reaktif yaklaşımı tercih etmişlerdir. Almanya ise izlemiş olduğu genel politika kapsamında proaktif, krizin önlenememesi ve vaka ve ölüm saylarındaki artış sonrası ise reaktif yaklaşımı benimsemiş ve bu doğrultuda adımlar atmıştır. Araştırmada ele alınan ülkeler genel olarak değerlendirildiğinde, vaka ve ölüm oranlarına bakıldığında en başarılı ülkenin Çin olduğu ikinci sırada Türkiye'nin geldiği onu Almanya'nın izlediği tespit edilmiştir. ABD ve İtalya ise çalışmada incelenen ülkeler içinde krizi yönetme biçimlerine ve vaka ve ölüm oranlarına bakıldığında en başarısız ülkeler olarak ortaya çıkmışlardır.

\section{Extended Abstract}

Emerging in Vuhan city of China and spreading throughout the entire world in a very short time, Coronavirus pandemic has turned into a crisis which has become difficult for all countries in the world to deal with for nearly one year. Not being taken so serious when first identified in Chine and considered to be confined in a specific area, this pandemic has unfortunately taken more than 1 million lives and is still going on throughout the world.

The study attempts to present comparatively which crisis approach do the countries that encounter with such a massive pandemic prefer in case of such crisis and whether the approach they prefer brings them success. It was also analyzed which measures the countries had taken to stop spread of the pandemic and whether such measures that are taken had served for the purpose in stopping or slowing down the pandemic.

The study takes China, the USA, Turkey, Germany and Italy as sample. Such countries being in the top ten in the worldwide pandemic listing as of April $20^{\text {th }}, 2020$ was considered a determinative factor for their selection and also, such countries being prominent in terms of both their healthcare systems and the measures they have taken against pandemic was a factor for being taken as sample. Employing literature review method that takes scientific observation into consideration, the study has analyzed the measures taken against the crisis by China, the USA, Turkey, Germany and Italy the steps they have taken comparatively. The study emphasizes attributes of the pandemic crises such as spreading rates, areas of effect and aims to present how covid-19 crisis is managed in China, the USA, Turkey, Germany and Italy. In the study, the countries were classified as successful, unsuccessful and moderately successful and number of cases and mortality rates were taken as basis in such classification.

It was seen in the result of the study that China, as the country where the disease outbreak had occurred, has responded to this pandemic crisis very quickly. This country differs from other countries due to the measures with high sanction power. Vuhan city, where coronavirus broke out was immediately locked out from other cities and countries. China succeeded to take the pandemic under control very quickly as short as 1.5 month with those measures taken.

It will not be wrong to state that the USA has failed in Coronavirus crisis. Despite the fact that the USA government was aware of the pandemic well in advance, it failed to perceive the severity of the problem, was late to take required measures and became the country which was affected by the pandemic the most. The country took the first place in the World Coronavirus rating in terms of case and mortality rates also in the second wave as it had been in the first wave.

Despite the USE, Turkey has approached to this problem seriously when the pandemic broke out for the first time and started to take measures before Coronavirus pandemic had reached to the borders of the country. This caused decrease in the spreading rate of the disease in the country. Having a reliable healthcare system and sufficient quantities of medical equipment particularly due to the investments in the healthcare sector in the recent years has led Turkey to manage this crisis more successfully than other countries. 
A different picture can be seen in Germany with regard to the course of the pandemic. Although German government did not take serious measures against Coronavirus pandemic in the beginning, number of cases and mortality rates were lower than other European countries. It can be said that this is a result of the disease being spread mostly among young people and kinship relations being different than other countries. Also, strong healthcare infrastructure of the country and the number of tests that were applied being more than other countries can be considered among other aspects which caused the country to be successful in fighting against Coronavirus.

Another country which was dealt within scope of the study is Italy. Italy has been one of the countries which experienced the first wave of Coronavirus the most severely. Coronavirus was spread in this country very quickly. Failure of the country's government to take timely measures as required during the pandemic process, failures in the crisis planning and shortages in the healthcare system has caused the country to become the one where the highest number of cases and mortalities had occurred in Europe.

In conclusion, countries which have invested in the healthcare system by anticipating such crisis and have taken required measures through accurate planning by comprehending the severity of the disease were seen to manage this crisis better in this crisis which was caused by a pandemic. In other words, it was established that countries which adopted a more proactive crisis management approach in the face of Coronavirus crisis had realized a more successful crisis management than other countries while the countries which failed to adopt a proactive crisis management approach and were caught unprepared for this pandemic were unsuccessful in managing this crisis.

\section{Kaynakça}

Akar, H. (2014). Kriz Yönetiminde Halkla İlişkiler Uygulayıcılarının Rolleri. İçinde Mustafa Akdağ ve Ümit Arklan (Ed.), Kriz Yönetimi İletişimsel Temelde Çözüm Odakh Stratejik Yaklaşımlar. (ss. 443-466). Konya: Literatürk.

Akat, İ., Budak, G., \& Budak, G. (2002). İsletme Yönetimi. İzmir: Fakülteler Kitabevi.

Akdağ, M. (2005). Halkla İlişkiler ve Kriz Yönetimi. Selçuk. Üniversitesi Sosyal Bilimler Enstitiusü Dergisi, 14, $1-20$.

Arklan, Ü. (2014). Kriz, İtibar ve Yönetimi: Spesifik Süreçte Yaşamsal Bir Etkileşim. İçinde Mustafa Akdağ ve Ümit Arklan (Ed.), Kriz Yönetimi İletişimsel Temelde Çöæzüm Odakl Stratejilk Yaklaşımlar. (ss. 205264). Konya: Literatürk.

Ataman, G. (2001). Issletme Yönetimi, Temel Kavramlar ve Yeni Yaklaşımlar. İstanbul: Türkmen Kitabevi.

Can, H. (1999), Organizasyon ve Yönetim. Ankara. Siyasal Kitabevi.

Combs, T.W. (2012). Ongoing Crisis Communication, Planning, Managing and Responding. London. Sage

Publication.

Dinçer, Ö. (2004). Stratejïk Yönetim ve Işsletme Politikası. İstanbul. Beta Yayınc1lık.

https://www.bbc.com/news/world-asia-52482553 (Erişim Tarihi: 03.07.2020).

Genç, N. (2005). Yönetim ve Organizasyon, Cağdaş Sistemler ve Yaklaşımlar. Ankara: Seçkin Yayıncillk.

Haşit, G. (2000). Issletmelerde Kriz Yönetimi ve Türkiye'nin Büyük Sanayi Issletmeleri Üzerine Yapılan Arasstrma

Çalıs̆ması. Eskişehir: Anadolu Üniversitesi Açık Öğretim Fakültesi Yayınları:616.

https://haberler.boun.edu.tr/tr/haber/salginla-mucadelede-ulkelerin-dogru-ve-yanlislari (Erişim

Tarihi: 20.07.2020).

https://medyascope.tv/2020/04/05/koronavirus-zaman-cizelgesi-ne-zaman-ortaya-cikti-nasil-yayildi-

onemli-tarihler-nelerdi/ (Erişim Tarihi: 17/04/2020)

https://www.aa.com.tr/tr/analiz/almanyanin-kovid-19-karnesi/1819866 (Erişim Tarihi: 21/10/2020)

https://www.aa.com.tr/tr/analiz/italya-da-koronavirus-travmasi/1767496 (Erişim Tarihi:

$21 / 10 / 2020)$

https://www.aa.com.tr/tr/koronavirus/yeni-tip-koronavirus-salgininin-gelisimi-/1756549 (Erişim

Tarihi: $18 / 04 / 2020)$

https://www.amerikaninsesi.com/a/kronoloji-dunya-2020ye-corona-virusuyle-girdi/5314885.html

(Erişim Tarihi: 04.07.2020).

https://www.bbc.com/turkce/haberler-dunya-51809558 (Erişim Tarihi: 22/10/2020).

https://www.bbc.com/turkce/haberler-dunya-52053276 (Erişim Tarihi: 19.07.2020). 
https://www.bbc.com/turkce/haberler-dunya-53819417 (Erişim Tarihi: 22/10/2020)

https://www.bbc.com/turkce/haberler-turkiye-52899914. (Erişim Tarihi: 05.07.2020).

https://www.bbc.com/turkçe/haberler-dünya-52200598 (Erişim Tarihi: 21.07.2020)

https://www.ekonomist.com.tr/haberler/italyada-ne-oldu-koronavirus-vaka (Erişim

Tarihi:

22/10/2020).

https://www.milliyet.com.tr/italya-da-corona-virus-neden-bu-kadar-hizli-yayildi--molatik-

14622/?Sayfa=7 (Erişim Tarihi: 21/10/2020).

https://www.vox,com/2020/3/18/21185065/congress-coronavirus-tests-paid-sick-days,

Tarihi: 5.04.2020).

https://www.whitehouse.gov/presidental-actions/proclamation-suspension-entry immegrants-nonimmigrants-persons-pose-risk-transmitting-2019-novelcoronavirüs (Erişim Tarihi: 5.04.2020).

https://www.worldometers.info/coronavirus/ (Erişim Tarihi: 21/10/2020).

https://www.yenihaberden.com/analiz-trumpin-secim-hesaplarina-virus-darbesi-1458007h.htm

(Erişim Tarihi: 20.07.2020).

Kazanc1, M. (2014). Kriæ Dönemleri ve Kuruluslar. M. Akdağ ve Ümit Arklan (Ed.), Kriz Yönetimi:

İletişimsel Temelde Çözüm Odaklı Stratejik Yaklaşımlar içinde (17-32 s.s) Konya: Literatürk Yayınları.

Kernisky, D. A. (1997). Proactive Crisis Management and Ethical Discourse: Dow Chemical's İssues

Management Bulletins 1979-1990, Journal of Business Ethics, 16(8), 843-853

Kırdar, Y., Demir, O. F. (2007). "Kriz İletişim Aracı Olarak İnternet: Kuş Gribi Krizi Örneği”, İstanbul

Üniversitesi İletisim Fakëlltesi Dergisi, 29, 93-106.

Kireçci, M. A. (2020). https://kriterdergi.com/dis-politika/covid-19-ve-ic-kirilganliklar-kiskacinda-abd)

Mackenzie, A. (1995). Başarn ve Zaman. (Çev. Gürcan Banger). İstanbul: Bilim Teknik Yayınevi

Manzoni, A.(2015).CrisisManagement, https://www.researchgate.net/publication/282858333

Miş, N. Koronavirüs Mücadelesinde Türkiye, ABD, AB ve İngiltere'nin Devlet Kapasitesi.

https://kriterdergi.com/siyaset/abd-ve-ingiltere-sinifta-kalirken-turkiyenin-guclu-devlet-kapasitesi-

koronavirus-mucadelesinde-belirleyici-oldu (Erişim Tarihi: 16.07.2020).

Özdemir, L. (2014). 2008 Küresel Ekonomik Krizinin Örgütsel Etkileri ve Bir Ölçek Geliştirme.

Yönetim Bilimleri Dergisi. 12. 23. 79-105.

Peker, Ö. \& Aytürk, N. (2000). Etkili Yönetim Becerileri. Ankara: Yarg1 Yayınevi.

Pira, A. \& Sohodol, Ç. (2004). Kriz Yönetimi-Halkla İlişkiler Açısindan Bir Değerlendirme. İstanbul: İletişim Yayınlar1.

Regester, M. (1989). Crisis Management. London: Business Books

Semercioğlu, H. (2007). Kriz Yönetimi. www.academia.edu.tr.

Solmaz, B. (2006). Halkla İlişkilerde Reaktif ve Proaktif Stratejiler. İstanbul Üniversitesi İletişim Fakültesi Dergisi. 25, 143-154.

Tağraf, H. \& Arslan, N. T. (2003). Kriz Oluşum Süreci ve Kriz Yönetiminde Proaktif Yaklaşım”, C.Ü. İktisadi ve İdari Bilimler Dergisi, 4 (1), 149- 160.

Tutar, H. (2007). Kriz̨ve Stres Yönetimi. Ankara. Seçkin Yayıncilık.

Ural, E. G. (2003). "Kriz Yönetiminde Proaktif Halkla İlişkiler Yaklaşımları ve Konu-Gündem Yönetimi”, Afjon Kocatepe Üniversitesi IIBBF, 11. Ulusal Yönetim ve Organizasyon Kongresi Bildiri Kitabr içinde (381391) Ankara: Uyum Ajans.

Uzun, D. (2001). "Otel İşletmelerinin Krize Hažrllkel Olma Durumlarmmn Değerlendirilmesi, Beş Yuldą̧l Otellerde Bir Uygulama”, Yayınlanmamış Yüksek Lisans Tezi, Mersin Üniversitesi Sosyal Bilimler Enstitüsü, Mersin. 